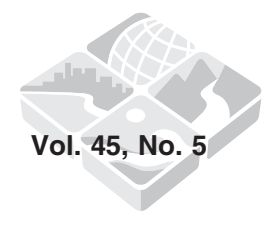

\title{
INSTREAM FLOW SCIENCE FOR SUSTAINABLE RIVER MANAGEMENT¹
}

\author{
Geoffrey E. Petts ${ }^{2}$
}

\begin{abstract}
Concerns for water resources have inspired research developments to determine the ecological effects of water withdrawals from rivers and flow regulation below dams, and to advance tools for determining the flows required to sustain healthy riverine ecosystems. This paper reviews the advances of this environmental flows science over the past 30 years since the introduction of the Instream Flow Incremental Methodology. Its central component, Physical HABitat SIMulation, has had a global impact, internationalizing the e-flows agenda and promoting new science. A global imperative to set $e$-flows, including an emerging trend to set standards at the regional scale, has led to developments of hydrological and hydraulic approaches but expert judgment remains a critical element of the complex decision-making process around water allocations. It is widely accepted that river ecosystems are dependent upon the natural variability of flow (the flow regime) that is typical of each hydro-climatic region and upon the range of habitats found within each channel type within each region. But as the sophistication of physical (hydrological and hydraulic) models has advanced emerging biological evidence to support those assumptions has been limited. Empirical studies have been important to validate instream flow recommendations but they have not generated transferable relationships because of the complex nature of biological responses to hydrological change that must be evaluated over decadal time-scales. New models are needed to incorporate our evolving knowledge of climate cycles and morphological sequences of channel development but most importantly we need long-term research involving both physical scientists and biologists to develop new models of population dynamics that will advance the biological basis for 21st Century e-flow science.
\end{abstract}

(KEY TERMS: e-flows; PHABSIM; withdrawals; dams; river ecosystems.)

Petts, Geoffrey E., 2009. Instream Flow Science for Sustainable River Management. Journal of the American Water Resources Association (JAWRA) 45(5):1071-1086. DOI: 10.1111/j.1752-1688.2009.00360.x

\section{INTRODUCTION}

After 50 years of international concern about the ecological impacts of flow alteration and 30 years of research to advance the science of instream or e-flows (hereinafter referred to as e-flows) there is evidence to suggest that a pivotal point has been reached in acknowledging (1) the importance of conserving river- ine ecosystems and (2) the need to allocate water for environmental needs. The history has been reviewed by many authors in research monographs (e.g., Petts, 1984), academic handbooks for practitioners (e.g., Petts and Maddock, 1994; Stalnaker, 1994), in-depth academic reviews (e.g., Petts, 2007), critical case studies (e.g., on the Klamath River Basin, NRC, 2008), and major works aimed at promoting the e-flows agenda to a wider audience (Postel and Richter, 2003;

\footnotetext{
${ }^{1}$ Paper No. JAWRA-08-0225-P of the Journal of the American Water Resources Association (JAWRA). Received December 3, 2008; accepted June 1, 2009. ( 2009 American Water Resources Association. Discussions are open until six months from print publication.

${ }^{2}$ Vice Chancellor (President), The University of Westminster, 309 Regent Street, London W1B 2UW, United Kingdom (E-Mail/Petts: g.petts@westminster.ac.uk).
} 
Annear et al., 2004). This history highlights the separate developments in physical and biological sciences and the progressive acceleration of research effort and innovation in advancing tools for setting $e$-flows to regulate rivers and manage water abstractions (withdrawals).

It is now widely accepted that human water demands must be balanced with the needs of rivers themselves but tensions in water resource allocation are intensifying. This is not only because of growing human demands, especially for food and energy security, but also because of uncertainties in the face of climate change and in our knowledge of the water needs of riverine ecosystems. In this context, the conservation of biodiversity, improvement in ecosystem health, and restoration of ecosystem integrity are rarely prioritized by governments even though they may be embedded in strategy documents (Petts et al., 2000). Estimates suggest that by 2050 many countries will face water scarcity, placing increasing pressures on the water-dependent ecosystems of rivers and estuaries. However, the fear of flood and drought, concern for food and energy security, and the priority to advance "limitless economies" that drove water-resource development 50 years ago (Thomas, 1956, p. 408) continue to relegate the conservation of riverine ecosystems to "luxury" status in setting political agendas.

A 21st Century "e-flows imperative" has evolved as confidence has grown in our scientific knowledge, from experience of applying scientifically informed tools, and from increasingly detailed and quantitative analyses of the ecological effects of flow regulation and abstraction. The advancement of ecologically sound tools for setting e-flows is important for all levels of sustainable water-resources management. First, tools are needed to predict the ecological effects of abstractions and flow regulation, and for determining the flows needed to sustain healthy riverine ecosystems. Second, where technological solutions to water shortage involve "control by construction," with large dams, major abstractions, and inter-basin transfers, it is necessary to determine the water volume or "reserve" to provide a flow regime that will conserve water-dependent ecosystems. Third, such determinations are also critical in high-level decisions about national and regional investments such as in desalination to supply the growing maritime urban conurbations and in the "virtual water" of international and regional food trade to reduce unsustainable irrigation agriculture in dry regions (Rogers, 2008). These investments could reduce demands on the "fluvial resource" and increase the potential water allocations to protect riverine ecosystems. This paper offers a critical and international state-of-thescience perspective to place this "e-flows imperative" in context.

\section{THE BIRTH OF E-FLOW SCIENCE}

A step-change in scientific endeavor during the late-1970s (Table 1) gave rise to $e$-flow science. It was driven by a practical need: the threat to fisheries posed by application of a single minimum flow as the basis for issuing water permits in many of the states in the United States (U.S.) (Stalnaker, 1994). This driver built on a tradition in the U.S. of managing flows as a tool to meet the wastewater load assimilation standard required by the Clean Water Act. The motivation to manage river flows for river ecology, particularly populations of migratory fish, was formally established in the U.S. at a multidisciplinary symposium significantly co-sponsored by the American Fisheries Society and American Society of Civil Engineers (Orsborn and Allman, 1976). In fact, the principle had been embedded in legislation within many developed nations for more than 100 years. For example, in the United Kingdom, Private Acts of Parliament toward the end of the 19th Century made provision for flows below dams, taking account of navigation, public health, the rights of downstream users, and the protection of fisheries (Sheail, 1984, 1988). The Water Resources Act 1963 required the River Authorities to set "minimum acceptable flows" and since then all new abstraction licenses have contained conditions to protect the water environment where necessary (Petts, 1996). These conditions include "hands-off" flows that require abstractions to cease when flows fall below a specified level, and "maintained flows" that under certain low-flow conditions require river support by groundwater pumping or reservoir releases. However, until the late 1970s e-flow recommendations were based on the "professional judgment" of a biologist or engineer rather than on a quantified evaluation of the relationships between discharge and the ecology of a stream (Fraser, 1972). In both the U.S. and United Kingdom protection for fish was provided by a defined "minimum flow," often a fixed percentage of average flows, typically $20 \%$ of the daily average flow (Baxter, 1961; Tennant, 1976) or, as used in the United Kingdom, a low-flow duration statistic, the 95th percentile flow $\left(Q_{95}\right)$. The use of a flow-duration statistic as a minimum ecological flow may be seen as a more consistent benchmark because the ratio of $Q_{95}$ to the mean flow varies in relation to the flow regime of natural rivers (typically in the range 10 to $40 \%$ ).

The roots of e-flow science (Table 1) are found in (1) description of flow regimes at global (Parde, 1955) and regional (e.g., for U.S. and Canada) (Bruce and Clark, 1966; Langbein and Wells, 1955) scales; (2) the quantification of the spatial and temporal variations of fundamental hydraulic parameters (flow velocity, 
TABLE 1. The Evolution of E-Flow Science: A Chronology.

\begin{tabular}{|c|c|c|}
\hline E-flows Tools (references) & Year & Key Scientific Publications and Events (references) \\
\hline \multirow[t]{2}{*}{$\begin{array}{l}\text { New focus on } e \text {-flow } \\
\text { standards (Poff } \text { et al.) }\end{array}$} & 2009 & $\begin{array}{l}\text { 1st International Symposium of the International Society for River Science, } \\
\text { St. Petersburg, Florida }\end{array}$ \\
\hline & 2004 & "Instream Flows for Riverine Resource Stewardship" (Annear et al., 2004) \\
\hline $\begin{array}{l}\text { Holistic approach } \\
\text { advanced (King et al., 2003) }\end{array}$ & 2003 & \\
\hline \multirow{3}{*}{$\begin{array}{l}\text { IFIM reported to have been } \\
\text { used in more than } 20 \\
\text { countries (Tharme, 2003) }\end{array}$} & 2000 & Cape Town Symposium on Environmental Flows for River Systems (RRA, 2003) \\
\hline & 1998 & $\begin{array}{l}\text { Building Block Methodology advanced for rivers with limited data especially } \\
\text { in South Africa and Australia (e.g., King and Louw, 1998; see also } \\
\text { Arthington et al., 2003; King et al., 2003) }\end{array}$ \\
\hline & 1997 & "The natural flow regime paradigm" (Poff et al., 1997) \\
\hline \multirow[t]{3}{*}{$\begin{array}{l}\text { Hydrological alteration } \\
\text { method (Richter et al., 1996) }\end{array}$} & 1996 & $\begin{array}{l}\text { "A general protocol for restoration of regulated rivers" (Stanford et al., 1996) } \\
\text { 1st International Symposium on Habitat Hydraulics, Trondheim, Norway (Saltveit) }\end{array}$ \\
\hline & 1980-1995 & $\begin{array}{l}\text { A period of consolidation and spread of e-flows research and applications: } \\
\text { e.g., "The Rivers Handbook" Volume } 2 \text { (Calow and Petts, 1994); "In-stream } \\
\text { flow management in Australia" (Arthington and Pusey, 2003); "Hydraulic } \\
\text { stream ecology" (Statzner et al., 1988); "Impounded Rivers" (Petts, 1984) }\end{array}$ \\
\hline & 1987 & $\begin{array}{l}\text { Launch of new international journal: Regulated Rivers: Research and } \\
\text { Applications (expanded as River Research and Applications in 2002) }\end{array}$ \\
\hline \multirow[t]{2}{*}{ IFIM (Bovee, 1982) } & 1982 & \\
\hline & 1979 & $\begin{array}{l}\text { 1st International Symposium on Regulated Streams, Erie, Pennsylvania } \\
\text { (Ward and Stanford, 1979); "Fisheries Ecology of Floodplain Rivers" (Welcomme, 1979) }\end{array}$ \\
\hline IFIM (Bovee, 1978) & 1978 & $\begin{array}{l}\text { IFIM principles transferred to determine instream flow requirements of } \\
\text { benthic macroinvertebrates (Gore, 1978) }\end{array}$ \\
\hline \multirow{6}{*}{$\begin{array}{l}\text { Boise Symposium } \\
\text { (Orsborn and Allman, 1976) }\end{array}$} & 1976 & \\
\hline & $1965-1976$ & $\begin{array}{l}\text { Ecological effects of flow regulation below dams elucidated (e.g., Penaz et al., 1968; } \\
\text { Gill, 1971; Davies et al., 1975; Armitage, 1976; Ward, 1976) }\end{array}$ \\
\hline & 1970 & “The Ecology of Running Waters" (Hynes, 1970) \\
\hline & 1965 & Launch of International Hydrological Decade \\
\hline & 1955 & 1st descriptions of river flow regimes (e.g., Langbein and Wells, 1955; Parde, 1955) \\
\hline & 1953 & $\begin{array}{l}\text { Hydraulic geometry approach to describing in-channel flows introduced } \\
\text { (Leopold and Maddock, 1953) }\end{array}$ \\
\hline
\end{tabular}

depth, and width) with changing discharge pioneered by Leopold and Maddock (1953); and (3) the conceptualization of ecological responses to these variations of flow and hydraulics advanced by Hynes (1970). Advances worldwide were dependent on improved data collection not least for river flows, and this was driven forward by the International Hydrological Decade initiated from January 1965 by 57 nations meeting at UNESCO, especially for catchments of up to $250 \mathrm{~km}^{2}$ considered to be representative of each major hydrological region. Through the same decade there was also a major increase in concern for the ecological effects of flow regulation. Gill's (1971) theoretical assessment of the long-term influence of river impoundment on the ecology of the Mackenzie River Delta and the detailed analysis of the influence of the Vir Valley reservoir on the ecology of the Svratka River, Czechoslovakia by Penaz et al. (1968) illustrate the emergence of interdisciplinary case studies. Two themes came to provide the core of e-flows science: (1) the ecological effects of dams (Armitage, 1976; Ward, 1976) and (2) the role of the flood regime in sustaining the fisheries of large rivers (Welcomme, 1979). Then "The Ecology of Regulated Streams" (Ward and Stanford, 1979) provided the catalyst for interna- tional, interdisciplinary advances. Thirty years later, the basic knowledge needed to formulate policy decisions and management approaches on water allocations to meet environmental needs along rivers has been elaborated.

Ward and Stanford's volume was the product of the First International Symposium on Regulated Streams. This was followed by another nine triennial symposia that led to the launch of the International Society for River Science (in 2006); it spawned a symposia series on Habitat Hydraulics (from 1996), and the establishment of a journal (Regulated Rivers now River Research and Applications - published by Wiley from 1987) dedicated to the advancement of science for sustainable river regulation (Table 1). From 1980 to 1995, e-flows science was advanced, dispersed, assimilated into practice, and challenged. But by the end of this phase of development, a general protocol had been established for restoring regulated rivers (Stanford et al., 1996), the natural flow paradigm (Poff et al., 1997) had become embedded in e-flow science and common in practice, and new methods were being developed to address rivers with limited empirical data and approaches advanced to set regional flow standards. The association between flow 
variability and the health of river ecosystems became the center of the U.S. Instream Flow Council Guidance (Annear et al., 2004) but even after 30 years, the philosophy of using simple operational rules fundamentally based upon minimum flows for single species remains widespread (Arthington et al., 2006; Poff et al., 2009).

\section{Basic Principles}

The ecological integrity of riverine ecosystems depends on their natural dynamic character (Poff et al., 1997). The fundamental ecological principle for the sustainable management of riverine ecosystems is the need to sustain flow variability that mimics the natural, climatically driven variability of flows at least from year to year and from season to season, if not from day to day (Naiman et al. 2002). This includes the important role of floods as well as instream flows. For example, floods can make available critical spawning/nursery habitat to fish when lateral habitat connectivity provides critical slack water refugia for species during periods of severe in-channel disturbance. Thus, the two fundamental general principles are:

(1) The natural flow regime shapes the evolution of aquatic biota and ecological processes and

(2) Every river has a characteristic flow regime and an associated biotic community.

However, the "flow regime" is a complex concept. Flow regimes typical of each hydro-climatic region are usually derived from hydrological series of 1220 years. These represent average conditions created by combining a small number of flow regime types, particular to each hydro-climatic region (e.g., Harris et al., 2000). They reflect inter-annual variability in hydro-climatological conditions; they relate to different sequences of synoptic weather patterns and can produce an annual cycle - "hydrological year" - ranging from 10 to 15 months. Thus, the typical flow regime based upon mean monthly flows is itself a simplified form of the more variable natural pattern of flows (e.g., Table 2). Furthermore, the linkages between flow regime and ecological health are complex in both time and space. The "natural dynamic character" relates not only to flow variability but also to water quality, especially temperature variations, sediment dynamics, and channel dynamics (that are also influenced by patterns of woody vegetation growth), changes in food/energy supply, and interactions between biological populations. This level of complexity over decadal time-scales has frustrated scientific developments. Nevertheless, Bunn and Arthington (2002) summarized this complexity as four specific principles for advancing the provision of e-flows:

(1) Flow is a major determinant of physical habitat in rivers, which in turn is a major determinant of biotic composition.

(2) Maintenance of the natural pattern of habitat connectivity (a) along a river and (b) between a river and its riparian zone and floodplain is essential to the viability of populations of many riverine species.

(3) Aquatic species have evolved life history strategies primarily in response to the habitats that are available at different times of the year and in both wet and dry years.

(4) The invasion and success of exotic and introduced species along river corridors is facilitated by flow regulation, especially with the loss of natural wet-dry cycles.

TABLE 2. Inter-Annual Variations of the Flow Regime Within the Mesothermal, Mid-Latitude, Temperate Maritime Hydro-Climatic Zone Based Upon Analysis of Flow Data (1977-1997) From Four Major Rivers Across the United Kingdom (after Harris et al., 2000).

\begin{tabular}{|c|c|c|c|}
\hline Regime Type & $\begin{array}{c}\text { Number of } \\
\text { Station-Years }(\%)\end{array}$ & Regime Characteristics & Start of Hydrological Year ${ }^{1}$ \\
\hline Maritime temperate & & $\begin{array}{l}\text { High-flow season - December to February } \\
\text { Low-flow season - June to August }\end{array}$ & September \\
\hline Variant A & $21(26)$ & $\begin{array}{l}\text { Single November peak or dominant } \\
\text { November peak with secondary peak in April }\end{array}$ & August to October \\
\hline Variant B & $41(51)$ & December to January peak & August to September \\
\hline Variant C & $13(16)$ & $\begin{array}{l}\text { Major peak in March with secondary } \\
\text { peak in December }\end{array}$ & September \\
\hline Variant D & $5(6)$ & $\begin{array}{l}\text { Winter drought with no dominant peak } \\
\text { and typically a very dry January }\end{array}$ & September to October \\
\hline
\end{tabular}

Notes: In terms of flow magnitude, the 80 station-years comprised 70\% (56) "normal" flow years, 12\% (10) high-flow years, and 18\% (14) lowflow years.

${ }^{1}$ Defined as the end of the dry season marked by a change from negative to positive catchment water storage and a rise in natural base flow. 


\section{IN SEARCH OF TOOLS FOR WATER RESOURCES MANAGEMENT}

Ward and Stanford's (1979) volume not only demonstrated the magnitude of worldwide stream regulation but also proposed directions for future scientific investigations on stream ecosystems altered by upstream impoundments. In that volume, Stalnaker's (1979) review of the emerging work of the Cooperative Instream Flow Service Group had a major impact on the development of $e$-flow research internationally. Their Instream Flow Incremental Methodology (IFIM) evolved as a flexible process for identifying, evaluating, and comparing potential solutions to water allocation conflicts. It integrated planning concepts of water supply, hydrological time series, and analytical hydraulic and water quality models with empirically derived habitat vs. flow functions designed to assist in formulating and evaluating alternatives. For the first time, the approach explicitly linked physical habitat (hydraulic) simulation with habitat evaluation criteria for species and life stages to display changing habitat usability with flow. This was based in part on the developing relationships between instream flows and biota in rivers regulated by dams (Bovee, 1978; Gore, 1978). The underlying premise was that populations, and then biodiversity in rivers, are limited by habitat events (Stalnaker et al., 1996). "Habitat suitability criteria" (HSIs) were introduced to describe how individuals of a species select the most favorable conditions in a stream but will also use less favorable conditions, with the preference for use decreasing where conditions are less favorable. This concept has been aggressively challenged over the past 30 years because of the lack of concordance between changes in suitable habitat and fish populations, its simplified approach to hydraulic habitat characterization (e.g., Gore and Nestler, 1988) and lack of biological realism (e.g., Orth, 1987). But these limitations were well understood. Thus, Gore and Nestler (1987) noted: "IFIM maximizes generality and prediction at the expense of ecological reality but this does not detract from its utility to analyse water resource issues." Furthermore, the scientific limitations of what rapidly became an attractive management tool proved important stimuli to advancing new science.

\section{The Global Impact of Physical HABitat SIMulation}

At the core of IFIM is the principle that physical habitat attributes provide an index of suitability for biota. Physical HABitat SIMulation (PHABSIM) integrates the changing hydraulic conditions with discharge and the habitat preferences of one or more selected species. The method relies on three principles: (1) the chosen species exhibits preferences within a range of habitat conditions that it can tolerate; (2) these ranges can be defined for each species; and (3) the area of stream providing these conditions can be quantified as a function of discharge and channel structure. In the majority of PHABSIM applications, $e$-flow guidelines have focused on the needs of a single species, usually a salmon or trout, although more advanced approaches considered the needs of different life stages. PHABSIM requires quality field data and this is often time consuming and expensive to obtain. The output is location specific.

Although the scientific weaknesses of PHABSIM have attracted considerable attention, the conceptual simplicity of the tool has made it popular worldwide and gave impetus to new research directed at establishing and understanding flow-biota relationships. First, the primary approach uses a simple 1-D hydraulic model but this fails to predict spatial patterns of velocity in natural rivers, although they are useful for determining average velocity variations with changing discharge. This weakness has been overcome by the increasing use of 2-D hydraulic models that can describe the spatial and temporal heterogeneity of hydraulic conditions and provide a link to mesohabitat patterns (Bovee, 1996; Hardy, 1998; Stewart et al., 2005; Crowder and Diplas, 2006). Second, considerable efforts have been spent on attempts to assess the ecological credibility of PHABSIM by demonstrating the biological significance of "carrying capacity" as a limiting factor of population size (Lamouroux et al., 1999; Kondolf et al., 2000). However, validation of the approach in biological terms has proved difficult not least in establishing discrete relationships between biological populations and the Weighted Usable Area from empirically derived habitat suitability curves. The biomass of a species or life stage within a community can vary because of biological processes such as reproduction, energetics, and mortality that may be influenced by one or more unspecified environmental factors. Indeed, the quality of the HSI may have the strongest influence on output quality. Indices based on frequency of occurrence of actual habitat conditions used by a target organism in a particular reach have been criticized as too simplistic but composite indices that combine habitat use or preference indices also involve many assumptions (Bovee, 1986; Vadas and Orth, 2001; Ahmadi-Nedushan et al., 2006). Nevertheless, PHABSIM has been supported in a legal context, has had widespread application as a management tool, and has provided ecologists with a voice in water-resource decision making in more than 20 countries (Tharme, 2003). From a practical perspective, 
there is no doubt that the accumulated experience of using PHABSIM means its strengths and weaknesses are well understood.

\section{DEVELOPMENTS IN INSTREAM FLOW TOOLS}

Most e-flow tools are built on a more or less complex physical element that uses hydrological or hydraulic data that have, or are assumed to have, biological significance. Some methods benchmark regulated rivers against natural ones using paired rivers or reaches, or historical (preimpact) or naturalized data series. Many of these are also dependent upon empirical data on the range of preferred to unsuitable habitat conditions for a target species, or life stage, and assume that spatially derived HSIs, are transferable to predict usable habitat variations with flow changes over time.

Societal demands for river ecosystem protection have accelerated the development of innovative, locally applicable methods and tools especially within regions having limited databases. However, there are also many examples where sophisticated, sciencebased models are being applied to specific problems. For example, Grand et al. (2006) used a cell-based model of backwater geometry, a pond-based temperature model, and a model of invertebrate production to investigate the effects of within-day flow fluctuations caused by hydro-power operations on nursery habitats for larval and juvenile Colorado pikeminnow (Ptychocheilus lucius) along the Green River below Flaming Gorge dam, Utah. At the other extreme, Liu and Men (2007) addressed the urgent need to set seasonal instream ecological flows along the intensively regulated Huai River, China, in the face of limited hydrological and ecological data, by developing a novel and pragmatic solution to determining monthly instream ecological water levels for four morphologically different reaches using the Manning equation and hydraulic rating based on generalized cross-sections, and available data on fish spawning habitat.

Tharme (2003) identified over 200 approaches that have been described for advising on e-flows in 44 countries. On the one hand, the 21st Century e-flows imperative has led to particularly innovative approaches for setting e-flows in ungaged catchments and along rivers having limited data, and for tools and methods that can be applied at low cost. On the other hand, increasing concerns about limits to available water resources have required greater certainty in determinations of water allocations to protect riverine ecosystems. By the early 1990s, approaches had expanded from the determination of instream flows to e-flows. Many schemes now addressed wider issues than instream flow needs - the hydraulic habitats - of one or a few species. These new approaches increasingly addressed the sustainability of communities and ecosystems within the whole river corridor. They incorporated the access of aquatic biota to seasonal floodplain and riparian habitats as well as the need for high flows for riparian species and floods to sustain the geomorphological dynamics of the river corridor (RRA, 2003). They also focused on the determination of ecologically acceptable flow regimes. From a scientific perspective, this challenged researchers to determine the magnitude of ecologically significant flows for different times of the year (the benchmark flows) that are then integrated to establish ecologically acceptable annual hydrographs (e.g., Petts, 1996; Petts et al., 1999). It also required consideration of flow frequency and the ecological significance of different time-series of hydrological events over a period of years. The combination of ecologically acceptable hydrographs for "normal," "wet," and "dry" year scenarios, of particular frequency, is needed to establish ecologically acceptable flow-duration curves. The benchmark flows inform short-term and local operational rules; the hydrographs inform seasonal and short series of annual flow management; and the duration curves inform long-term water-resource planning.

The scientific imperative to set e-flows has progressed by advancing two types of tools: hydrological approaches and habitat approaches. But the imperative to set flow regulation rules has also led to the rise in popularity of scientifically informed expert panel assessments.

\section{Hydrological Approaches}

Hydrological approaches involve analysis of historical daily flow records. Flow is considered as a simple proxy for a number of related parameters, which may have a key influence on habitat. The rationale is that hydrological approaches support the fundamental ecological principle for sustainable water-resources management: namely, the need to sustain flows that mimic the natural, climatically driven variability. Such approaches also move attention away from fish to consider the range of aquatic, wetland, and riparian habitats along the river corridor. Three issues often hinder the apparently simple and reasonable application of hydrological approaches. First, standards need to be set to apply an appropriate record length with at least 12 years being required for statistical integrity but longer records may be needed to incorporate variable weather patterns over decadal time-scales (e.g., Kelly and Gore, 2007). Second is the 
problem of providing for actual scales of variability in the magnitude and timing of flows and the natural frequencies of these flows (as illustrated in Table 2). Third is the issue of "naturalizing" the gaged flow regime. In many areas the pristine catchment has no relevance to the modern day. The hydrology of catchments characterized by long-term human interference - such as urban conurbations and intensive agriculture bears little resemblance to the hydrologic character of unmodified catchments in a given hydro-climatic region. The concept for such catchments may be to produce functionally diverse, self-regulating ecological systems (Petts et al., 2000). In reality this requires determination of the flow regime that would be sustained under current or future catchment conditions in the absence of existing dams, reservoirs, diversions, and abstractions.

Richter et al. (1996) introduced the "Indicators of Hydrologic Alteration" (IHA) method, which uses a range of hydrologic parameters for each year of flow record to characterize inter-annual variation before (reference period) and after flow regulation/abstraction. The IHA method has been shown to successfully characterize all of the major components of the flow regime (Olden and Poff, 2003) and the selection of key hydrologic parameters may be adapted to local circumstances. Richter et al. (1997) proposed that the statistical characterization of ecologically relevant hydrograph parameters could define the variability of the dimensions of the flow regime within which artificial influences should be contained. Their Range of Variability Approach (RVA) employed preimpact or naturalized flow series to establish IHA target ranges and this has been used to incorporate regime-based $e$ flows in water resources and environmental management in the U.S. (e.g., Richter et al., 1998, 2006; Mathews and Richter, 2007) and overseas (e.g., Shiau and $\mathrm{Wu}, 2004,2006)$. Galat and Lipkin (2000) for the Missouri River, recommended changes in reservoir management to return the regulated flows to within the pattern of natural variability, thereby simulating a natural riverine ecosystem. They argued that naturalization of the flow regime would not only benefit the ecological system but also the economic value of the river, once the products of agriculture, electricpower generation, and transportation are integrated with the socio-ecological benefits of a naturalized flow regime.

A focus on flow regimes has also spawned new research tools and new efforts to illuminate the significance of specific flows for biota. One example of the former is the use of wavelet analysis to assess dam operations in reconstructing desired flow characteristics (White et al., 2005) and analyzing temperature changes (Steel and Lange, 2007). The wavelet analysis provides an easy-to-interpret approach for investigating hydrological change when the management history is uncertain and time scales of important cycles are unknown. It allows examination of a range of temporal scales simultaneously and independently. A second example is the development of indices of overall hydrologic alteration (Shiau and $\mathrm{Wu}, 2007$ ) and a histogram matching approach that outperforms the RVA in preserving the natural flow variability (Shiau and $\mathrm{Wu}, 2008$ ). New efforts to illuminate the significance of different flows for biota stimulated by the e-flows imperative are illustrated by the use of a 20 -year paired flow and macroinvertebrate survey record for 83 rivers in England and Wales to highlight the ecological importance of (1) monthly flows and (2) the magnitude and duration of annual extreme flow conditions (Monk et al., 2006). Using Lotic Invertebrate Index for Flow Evaluation (Extence et al., 1999) scores, Monk et al. (2007a,b, 2008) demonstrated the significance of changes in runoff (mean annual discharge per unit catchment area) especially drought-years and wet-years on macroinvertebrate communities.

\section{Habitat Approaches}

Habitat approaches assume that biological communities have evolved to exploit the full range of mesohabitats; the variability of flows determining when and for how long mesohabitats are available to different species at different locations throughout the stream network. Each mesohabitat (termed biotope or functional unit in some studies) is a definable area such as a pool, riffle, or run that can be inferred by visual observation of surface flow character and verified by hydraulic measurements of velocities and depths, and qualitative or quantitative substratum types (Armitage et al., 1995; Newson and Newson, 2000). Habitat duration curves provide summary statistics on average habitat availability and these could be developed to consider periods of habitat persistence related to key biological time-windows.

The flooding regime leads to a particular configuration of aquatic and riparian habitats but the process of habitat creation and destruction results from the balance between rejuvenating flooding events and habitat stabilization and decay. Habitat turnover may be high along natural river corridors but at the sector scale (a geomorphologically distinctive river segment often of ca. $10 \mathrm{~km}$ in length) the composition and configuration of habitats remains relatively stable (Arscott et al., 2002), providing a continuity of habitat associations that are available to sustain biotic populations. Thus, at this spatial scale, the dynamics of habitat turnover may be ignored for the purpose of exploring habitat-biota relationships over 
short time-scales (e.g., less than five years). Within such time scales, instream hydraulics and, for marginal and riparian species, the frequency and duration of inundation/dessication are the dominant factors determining the physical environment in which organisms live.

Parasiewicz (2003) advanced a PHABSIM derivative, Meso-HABSIM, to map mesohabitats at different flows along extensive sections of a river, to establish the suitability of each mesohabitat for the dominant members of the fish community, and to derive rating curves to describe changes in relative areas of suitable habitat in response to flow. Meso-HABSIM focuses on mesoscale approaches to build on strengths of PHABSIM protocols while providing options for addressing large spatial scales appropriate for water-resource planning (Jacobson, 2008). A rational framework for modeling fish community response to changing habitat conditions developed by Bain and Meixler (2008) is appropriate for integrating with physical habitat modeling (Parasiewicz, 2008). The fish collection survey is the most effortintensive component of Meso-HABSIM but literaturebased evidence and expert opinion can be used and a "regional" approach allows transfer of habitat use models among rivers of similar "type" (Parasiewicz, 2007).

Many species have evolved or developed physiological or behavioral characteristics and strategies for utilizing particular habitats differently in rivers having different flow regimes although few studies have evaluated such "adaptations" with any rigor (e.g., Lytle and Poff, 2004). Those organisms with life history strategies cued to flow events and synchronized one or more life stages to long-term flow regime dynamics may be particularly sensitive to change in the timing of environmental cues. However, there are few studies that have attempted to model hydrological variability and river hydrodynamics in relation to species populations or the fluxes, which determine dispersal triggers, life cycle patterns, and drift densities of the instream fauna (Poff et al., 1997; Bunn and Arthington, 2002). Thus, attempts to argue the biological significance of mesoscale hydraulic habitat surveys appear premature. In any case, the attractiveness of the mesohabitat approach for managers is its practicality (Newson et al., 1998) for example in optimizing habitat diversity across a range of flows (e.g., Dyer and Thoms, 2006).

\section{Science-Informed Panel Assessments}

During the 1980s in the U.S. incremental methods provided the evidence for negotiation among interest groups and to decision makers for resolving conflicts
(Stalnaker, 1994). A multiuse ethic had evolved shifting focus from minimum flows to a "conservation" water budget and involving interdisciplinary teams managing flows in real time for people, habitats, fish, and wildlife. IFIM became a multiobjective planning exercise for the benefit of the range of stakeholders; it is heavily reliant on professional judgment to identify the "best" alternative and involves group planning to enable a negotiated resolution process. It also gained a perception of being too data-intensive and time-intensive, and too expensive. In many countries, the pace of reform of water policy (e.g., Australia) and/or the lack of scientific data, and political pressure to deliver e-flow recommendations in short time frames (often less than one year) and at low cost, has seen authorities rely heavily on multidisciplinary expert panels to assess e-flow needs (Cottingham et al., 2002; Young et al., 2004) and to define regional e-flow standards (Acreman et al., 2008; Poff et al., 2009).

King et al. (2003) have attempted to link the productivity of large floodplain rivers to their flow characteristics using a value-based system, Downstream Response to Imposed Flow Transformation (DRIFT). This provides a data-management tool for many types and sources of information, predictive models, theoretical principles, and "expert knowledge" of a panel of scientists. Arthington et al. (2003) applied DRIFT to establish $e$-flow requirements of fish in Lesotho rivers and contend that the methodology can provide a Best Practice Framework for conducting scientific panel studies, although they acknowledge that a number of risks with the approach remain. The main risk is a perceived lack of incentive for what could be considered to be costly monitoring and longer-term research to develop evidence of biota-flow relationships for supporting adaptive management.

The 21st Century e-flows imperative is being built on confidence in scientific understanding together with evidence from experience gained in practice and includes the setting of $e$-flow standards at regional scales. Thus, Arthington et al. (2006) proposed a generic approach involving classification of rivers into hydrological classes defined by aspects of natural flow variability and relating ecological condition to a flowimpairment gradient to develop and calibrate ecologically relevant flow standards. In the United Kingdom, driven by the EU Water Framework Directive that requires all Member States to begin the process to maintain or restore all surface water bodies to Good Ecological Status by 2015, an "expert panels" approach has been used to determine levels of "acceptable abstraction" in relation to the "ecological sensitivity" of river reaches. The approach incorporates two elements: consistent river classification, this being already embedded within the abstraction 
licensing scheme for England and Wales, and regional standards based upon a river typology (Acreman et al., 2008). In the U.S., Poff et al. (2009) achieved a consensus view from a panel of international scientists on a framework for assessing e-flow needs that combines a regional hydrological approach and ecological response relationships for each river type based initially on the literature, existing data, and expert knowledge. Stakeholders and decision makers then explicitly evaluate acceptable risk as a balance between perceived value of the ecological goals, the economic costs involved, and the scientific uncertainties. New approaches to numerical processing of qualitative knowledge of experts, using a fuzzy rule-based approach for developing composite Habitat Suitability Indices that incorporate multivariate effects of variables without needing to assume independence of the input parameters, offers potential for demonstrating the objective and rigorous basis of HSIs from expert judgment (Ahmadi-Nedushan et al., 2008).

\section{A FUTURE FOR E-FLOW SCIENCE}

Despite considerable efforts to develop the science of e-flows, a deterministic model of ecosystem health remains a distant objective (Petts et al., 2006). Complex abiotic-biotic interactions, historical contingencies, and chance events means that riverine ecosystems must be modeled in stochastic or probabilistic terms. A survey of the most recent 200 papers published in one journal devoted to flow-biota science, River Research and Applications (from volume 22, 2006), shows that effort is being sustained across a diverse range of interrelated research foci spanning the physical and biological sciences. Thirty-nine percent of the papers offered new scientific insights of habitat or biological dynamics, another $9 \%$ advanced new research tools and 12\% elaborated case studies of human impacts [dams, diversions, abstractions (withdrawals), channel engineering schemes, etc.]. Papers specifically on instream flows comprised $28 \%$ of the total with $10 \%$ being experimental studies. A further $12 \%$ focused on new tools for instream flow studies. The lessons learned from these will have significance for adaptive approaches although the transferability of these lessons remains to be tested.

The premise that healthy river ecosystems depend on maintaining the flow variability characteristic of each particular hydro-climatic region is widely accepted (Naiman et al., 2002). But a comprehensive understanding of the ways in which physical and biological processes interact to sustain the ecological integrity of rivers and streams remains to be elucidated. There is an urgent need to determine the variability of key abiotic parameters over a range of spatial scales, to measure and model the effects of these variations upon biota, habitats and ecosystems, to understand the time scales and mechanisms of ecosystem response to hydrological change, and to advance models for healthy rivers in "developed" catchment contexts. The European Aquatic Modeling Network has reviewed the state of the art in data sampling, modeling analysis, and applications of river habitat modeling (RRA, 2007). They discuss research needed to improve and develop new methods and models of assessing interactions between aquatic biota and riverine habitats, such as winter conditions for fish (Huusko et al., 2007); demonstration of the possible gains for both fish condition and hydropower production of managing flow and water temperature in a dynamic way (Halleraker et al., 2007); mesohabitat methods to assess flow change (Hardy et al., 2007); and the use of 3-D, Weighted Usable Volumes to replace WUA (Mouton et al., 2007). Furthermore, the survey of papers from River Research and Applications revealed the emergence of detailed monitoring studies of "controlled" restoration projects, representing $40 \%$ of the e-flow papers. Long-term coupled physical and biological monitoring programmes of instream flow restoration or river regulation schemes offer major opportunities to develop the databases needed for both blue-skies research and adaptive management. Such blue-skies studies could lead to new models of stream ecosystems and a new generation of e-flows tools.

Three broad areas of further scientific advancement are necessary to improve confidence in e-flow science: understanding climatic cycles, cycles of channel change, and population dynamics and then the integration of this new knowledge into biology-led river ecosystem models. A fourth need is to develop a common framework that integrates physical (hydrological and hydraulic) and biological processes (Petts et al., 2006).

\section{Climate Cycles}

Improved understanding of the relationships between atmospheric circulation, climate, and streamflow is vital given the great importance of fluvial processes to natural systems and water resources, especially in the light of recent and predicted climate change. The El Nino-Southern Oscillation is known to significantly influence climate variability around the globe, not least in semiarid regions (Molles and Dahm, 1990; Molles et al., 1992) and the processes linking southern low and high latitudes are increasingly 
understood (e.g., Housego et al., 1998). Around the North Atlantic, particular attention has been paid to the climatic and hydrologic implications of the North Atlantic Oscillation and Arctic Oscillation (Kelly and Gore, 2007). However, research on the effects of climate change have focused on stream temperatures rather than the direct effects of changes to flow regimes (e.g., HP, 1997). The need to develop analyses of more hydrologically meaningful climate variables beyond conventional time-averaged statistics is deemed particularly important. One approach classifies flow regime shape (form) and magnitude (e.g., Table 2) considers the whole annual hydrological cycle (Hannah et al., 2000; Harris et al., 2000) and is particularly useful for identifying large-scale patterns in flow and temperature regimes and their between-year stability, thus providing an important context for short-term, small-scale process-based research. Bower et al. (2004) developed and tested this approach to identify spatial and temporal patterns in intra-annual hydro-climatologic response. Further, they introduced a novel sensitivity index to assess river flow regimes' climatic sensitivity. These techniques were evaluated by application to a 25-year (1974-1999) time-series of river flow, air temperature, and rainfall for a sample of 35 United Kingdom river basins.

\section{Geomorphological Cycles}

Improved knowledge of the roles of channel dynamics over decadal time-scales is required to develop realistic models of riverine ecosystems. Along large rivers in natural settings within most biogeographical regions, channel morphology is determined by the interplay of valley gradient and width, flood magnitude and frequency, sediment supply, and the growth of woody vegetation. Patterns of channel development related to climatic fluctuations, variations in sediment delivery from subcatchments and riparian woodland development must be assessed in order to understand the dynamic baseline. "Cycles" of channel development may be initiated by catastrophic inputs of sediments and wood, associated with natural fires or landslips, or phases of high sediment delivery from tributary basins that drive periods of aggradation along the main channel. Biological factors may also induce morphological cycles. Although flow resistance initially increases from early successional to mid-successional stages, as vegetation ages and stem density decreases, vegetation may become less effective at providing flow resistance so that the geomorphological threshold for erosion could decline over time (McKenney et al., 1995). Vegetation plays an active role in developing heterogeneous channel forms through (1) biotic processes such as seed dispersal, vegetative regeneration and succession and (2) abiotic effects such as increasing flow resistance inducing sedimentation and decreasing bank erodibility. Wooded islands are characteristic of some sectors along many natural rivers and these sectors have particularly high species richness (Gurnell et al., 2005). However, the natural influences of flood disturbance, wood accumulation, vegetation growth, island development, and tree die-off cause island-dominated reaches to undergo cycles of island growth and decay that are related to cycles of aquatic habitat diversification and simplification (Gurnell and Petts, 2002).

\section{Biological Dynamics}

It is clear that river hydrodynamics affect aquatic organisms in various ways but it has proved difficult to determine general relationships from disparate case studies (Poff and Zimmerman, 2009). The effect on each individual depends on its particular characteristics (e.g., physiology) and consequently it varies with species, and even within single species it may vary with life stage and between rivers with different flow regimes, where organisms develop in environments with different stresses. Because populations vary over differing time scales, ranging from instantaneous mortality due to intolerable environmental conditions, seasonal variations due to reproduction and migration patterns, and cycles dictated by the typical life spans of the organisms, the overall effect of a given environmental condition may not be immediately apparent. It will, however, be evident as a long-term legacy on community distribution and functioning (e.g., Strayer et al., 2004). Furthermore, fish ecological research typically focuses on $0+$ fish, the most sensitive life stage, and on the spawning stock but age groups in between may also encounter bottlenecks (Huckstorf et al., 2008). There is an urgent need for more research on population dynamics in both "pristine" and degraded systems.

It is clear that major advances in understanding require long-term and coupled hydrological, hydraulic (reflecting the dynamics of channel morphology), and biological datasets. Understanding biological responses to habitat temporal variability is needed to identify the magnitude, duration and frequency of habitat-limiting periods on carrying capacity (Capra et al., 1995, 2003). Recent models of responses of trout populations to flow variability have suggested the importance of winter flows in determining recruitment (Cattanéo et al., 2002; Lobon-Cervia, 2003; Mitro et al., 2003), summer low flows that limit adult trout biomass and spring flows that limit the young-of-the-year numbers between emergence and their first summer (Sabaton et al., 1997; Gouraud 
et al., 2001). Also, Fausch et al. (2001) showed that rainbow trout introductions failed where fish emergence from gravel coincides with high flows. For floodplain rivers, Halls and Welcomme (2004) used an age-structured population dynamics model, incorporating density-dependent growth, mortality and recruitment to show that exploitable biomass of a common floodplain fish species is maximized by minimizing the rate of flood recession and maximizing the flood duration and area inundated. Such models are useful for developing and testing concepts, but their role as management tools remains limited until they can be validated by empirical studies involving multisite sampling.

\section{Convergence of Traditions}

The different traditions and conventions used by hydrologists, hydraulic engineers, and freshwater biologists exacerbate the difficulties of developing a common science framework for advancing the e-flows agenda. Physical scientists are developing suites of increasingly sophisticated tools that can be used (1) to predict river stage, velocity fields, and bedform as a function of discharge; (2) to predict velocity and shear stress at multiple points within the river channel; and (3) to simulate the bulk flow of water at a resolution sufficient to route stage and various conservative and nonconservative constituents. These tools simulate processes that can be approximated by the Eulerian-based approach by discretizing complex geometries with a grid (or mesh) and then applying sets of governing equations to each node, and they work well for simulating processes that are easy to aggregate into control volumes, such as water flow or water quality. Ecologists continue to make conceptual advances through empirical descriptions of how important riverine processes vary over time and space and these are being used to set general guidelines for conservation action on individual rivers. Such approaches are very useful from a heuristic or theoretical standpoint, but cannot be used a priori to address many river management issues, as they are insufficiently quantitative at the scale at which management decisions are often made (Petts et al., 2006).

There is a need, therefore, to promote the development of integrated approaches that will allow the tools of physical and biological scientists to be coupled together. A key factor is providing an appropriate representation for each ecosystem element contained in the model, and as each element may involve processes with markedly different scales of variation in time and space, the best results are often obtained by applying different simulation approaches for each element (Nestler et al., 2005). For example, environmen- tal conditions, commonly defined in terms of river hydrodynamics and water quality, can be simulated appropriately with Eulerian models. The value of a given environmental condition for the population can be simulated by a habitat suitability model and the response of the population to environmental conditions can be simulated with a population dynamics model. These last include individual-based models that simulate population dynamics as the result of local interactions between individuals and between individuals and their environment.

An elegant approach to integrating these different physical and biological models has been demonstrated by Morales et al. (2006a) for the analysis of freshwater mussel communities. The approach is 3-dimensional, coupled to physical hydrodynamic models and is species specific. It uses data on river hydrodynamics, substrate composition, water quality, and fish distribution within a river reach. An individual-based model simulates the population response to environmental conditions in terms of mortality, food competition, growth, reproduction, larvae and juvenile dispersion, and the movement of juvenile and adults in search of suitable habitats. These functional processes are simulated by applying traditional ecological concepts, like the basic bioenergetics equation, and novel ideas like adapting principles from sediment transport to simulate the passive dispersion of mussel larvae with the flow (Morales et al., 2006a). Thus, knowledge and information about the biology of mussels has been coupled with fundamental principles describing the dynamics of the physical system, to assess the overall evolution of the mussel population in space and time in a $10-\mathrm{km}$ reach of the Upper Mississippi River (Morales et al., 2006b). Such models are parameter rich and data hungry and are likely to remain as informative research tools. The basic HSI at the core of these approaches remain their major limitation.

\section{DISCUSSION AND CONCLUSIONS}

In most parts of the world, the 21st Century has witnessed recognition by governmental organizations of the e-flows imperative to sustain healthy riverine ecosystems. This e-flows imperative requires maintenance of "an appropriate," "ecologically acceptable" flow regime along rivers and tools to determine environmental water allocations: "appropriate" and "acceptable" volumes available for abstraction and "rules" to regulate abstractions and flows. No matter what tools are adopted, the setting of $e$-flows requires expert judgment to interpret model output; model ele- 
gance and sophistication does not allow abdication of responsibility by experts in making those judgments.

Over the past 30 years, there has been steady progress in developing models of ecological dynamics in relation to flow but advances in the physical sciences have become detached from developments in the biological sciences. The introduction of PHABSIM and HSIs in the late 1970s stimulated a generation of innovation and scientific advancement in response to both the perceived strengths, particularly its interdisciplinary focus, and scientific limitations. Then there was a second phase of practical innovation from the mid-1990s in response to the e-flows imperative, with two distinct strands developing (1) locally appropriate tools especially for ungauged rivers and (2) "holistic" approaches that seek to advance scientifically informed decision-support systems, building on the framework established by the IFIM. This most recent phase of innovation is being driven by a need to develop environmental standards especially for river systems with limited flow and biological data (Arthington et al., 2006; Poff et al., 2009).

Within the past decade the focus has been on improving the sophistication of physical models that are assumed to have biological significance. From a management perspective, there is no doubt that the focus on "habitat" has allowed significant progress to be made in addressing the e-flows imperative worldwide. Three levels of ecological assumptions continue to drive the advances in physical science even though these have received only limited scientific support over the past 30 years. First, the flow regime is assumed to shape the development of biotic communities. Second, "habitat" is assumed to be a major determinant of biotic composition with communities having evolved to exploit the full range of habitats. Third, "HSIs" are assumed not only to describe the spatial distribution of biota but also to reflect selectivity and preference by species. On some occasions and mistakenly, it has been assumed that these criteria can be transferred to predict changes with flow over time.

Mechanistic hydrodynamic modeling is being increasingly used to predict velocity and depth patterns in rivers from detailed surveys of channel morphology but a gap has been widening between the sophistication of physical flow and habitat models and the demonstration of fundamental biological mechanisms to support integrated models of flow-habitat-biota interactions (Schweizer et al., 2007). Many detailed case studies have demonstrated the sensitivity of biota to major hydrological change (e.g., Poff and Zimmerman, 2009), especially below dams, often pointing to migration bottlenecks, thermal effects or siltation as key mechanisms. However, relatively few of these empirical studies have fully elucidated the controlling mechanisms on biota. Field-based empirical studies leading to the development of ideas and concepts in descriptive terms are appropriate as the natural precursors to experimental and theoretical investigations that seek to elaborate the natural generating mechanisms for the patterns or anomalies illuminated by empirical studies. Too often they have been presented as ends in themselves. A key component of the necessarily long-term vision for advancing e-flows must be the development of biology-led (cf. physical process-led) models to evaluate the complex changes of communities and species that may be caused by changes in hydrological regime and availability of hydraulic habitats. Stimuli for such research would come from stronger and more effective connectivity between interdisciplinary science teams (involving pure and applied scientists), practitioners and policy makers.

"How much water does a river ecosystem need?" remains a challenging question. We now know it requires understanding of the direct and indirect interactions between flows and biota over a range of time and space scales. It requires consideration of flow variability and population dynamics over tens of years; it involves consideration of sector-scale habitat mosaics and of biological processes at finer scales of space and time. We know that fluvial systems are highly dynamic and respond to changes in flows and water levels in complex ways, and that changes caused by human impacts can be cumulative and may be irreversible. From a scientific perspective, commitment is needed to long-term research designed to better describe abiotic-biotic responses using coupled datasets and coupled analyses to elucidate fundamental mechanisms. The incorporation of climate variations, cycles of channel change, and improved population models over decadal time-scales is needed to advance realistic biological-response models. But this will require better engagement between physical scientists and the biological community. From a management perspective, there is still an infatuation with maximizing economic yield and a belief that technology provides the solution to environmental risks. Yet floods, droughts, moving channels, and variable populations of fish are characteristics of a healthy river. To educate politicians and the public about the importance of variability in sustaining riverine ecosystems is another major challenge that remains to be addressed.

\section{ACKNOWLEDGMENTS}

Sincere thanks to the IFC and all participants at Flow2008 for the opportunity to engage with the practical reality of dealing with e-flows issues. This review has benefited from debates and discussions with many colleagues over the years and in particular I 
would like to thank Jim Gore, Angela Gurnell, Jim Layzer, John Nestler, Bob Naiman, Jack Stanford, and James Ward. N. LeRoy Poff and two anonymous reviewers provided valuable contributions to this paper. I am also grateful to Brian Richter for his comments on early drafts and for editing the text into "American" English.

\section{LITERATURE CITED}

Acreman, M., J. Hannaford, O. Mountford, P. Wood, N. Holmes, I. Cowx, R. Noble, C. Extence, J. Aldrick, J. King, A. Black, and D. Crookall, 2008. Developing Environmental Standards for Abstractions From UK Rivers to Implement the EU Water Framework Directive. Hydrological Sciences Journal 53:11051120.

Ahmadi-Nedushan, B., A. St-Hilaire, M. Berube, T.B.M.J. Quarda, and E. Robichaud, 2008. Instream Flow Determination Using Multiple Input Fuzzy-Based Rule System: A Case Study. River Research and Applications 24:279-292.

Ahmadi-Nedushan, B., A. St-Hilaire, M. Berube, E. Robichaud, N. Thiemonge, and B. Bobee, 2006. A Review of Statistical Methods for the Evaluation of Aquatic Habitat Suitability for Instream Flow Assessment. River Research and Applications 22:503-524.

Annear, T., I. Chisholm, H. Beecher, A. Locke, P. Aarrestad, C. Coomer, C. Estes, J. Hunt, T. Jacobsen, G. Jöbsis, J. Kauffman, J. Marshall, K. Mayes, G. Smith, R. Wentworth, and C. Stainaker, 2004. Instream Flow for Riverine Resource Stewardship, revised edition. Instream Flow Council, Cheyenne, Wyoming.

Armitage, P.D., 1976. A Quantitative Study of the Invertebrate Fauna of the River Tees Below Cow Green Reservoir. Freshwater Biology 6:229-240.

Armitage, P.D., I. Pardo, and A. Brown, 1995. Temporal Constancy of Faunal Assemblages in Mesohabitats: Application to Management. Archive für Hydrobiologie 133:367-387.

Arscott, D.B., K. Tockner, D. van der Nat, and J.V. Ward, 2002. Aquatic Habitat Dynamics Along a Braided Alpine River Ecosystem (Tagliamento River, Northeast Italy). Ecosystems 5:802814.

Arthington, A.H., S.E. Bunn, N.L. Poff, and R.J. Naiman, 2006. The Challenge of Providing Environmental Flow Rules to Sustain River Ecosystems. Ecological Applications 16:1311-1318.

Arthington, A.H. and B.J. Pusey, 2003. Flow Restoration and Protection in Australian Rivers. River Research and Applications 19(5-6):377-395.

Arthington, A.H., J.L. Rall, M.J. Kennard, and B.J. Pusey, 2003. Environmental Flow Requirements of Fish in Lesotho Rivers Using the DRIFT Methodology. River Research and Applications 19:641-666.

Bain, M.B. and M.S. Meixler, 2008. A Target Fish Community to Guide River Restoration. River Research and Applications 24:453-458

Baxter, G., 1961. River Utilization and the Preservation of Migratory Fish Life. Proceedings of the Institution of Civil Engineers 18:225-244.

Bovee, K.D., 1978. The Incremental Method of Assessing Habitat Potential for Coolwater Species, With Management Implications. American Fisheries Society Special Publication 11:340-346.

Bovee, K.D., 1982. A Guide to Stream Habitat Analysis Using the Instream Flow Incremental Methodology. US Fish and Wildlife Service, Instream Flow Information Paper 12: FWS/OBS-82-26, Washington, D.C.

Bovee, K.D. 1986. Development and Evaluation of Habitat Suitability Criteria for Use in the Instream Flow Incremental Methodology. Instream Flow Information Paper, 21, US Fish and Wildlife Service Biological Report No. 86, Washington, D.C.
Bovee, K.D., 1996. Perspectives on two-Dimensional River Habitat Models: The PHABSIM Experience. Proceedings of the Second International Symposium on Habitat Hydraulics, INRS-Eau, Quebec, Canada, pp. B149-B162.

Bower, D., D.M. Hannah, and G.R. McGregor, 2004. Techniques for Assessing the Climatic Sensitivity of River Flow Regimes. Hydrological Processes 18:515-543.

Bruce, J.P., and R.H. Clark, 1966. Introduction to Hydrometeorology. Pergamon, London.

Bunn, S.E. and A.H. Arthington, 2002. Basic Principles and the Ecological Consequences of Altered Flow Regimes for Aquatic Biodiversity. Environmental Management 30:492-507.

Calow P., and G.E. Petts (Editors), 1994. The Rivers Handbook, 2, Blackwell Scientific Publications, Oxford, United Kingdom.

Capra, H., P. Breil, and Y. Souchon, 1995. A New Tool to Interpret Magnitude and Duration of Fish Habitat Variations. Regulated Rivers 10:291-289.

Capra, H., C. Sabaton, V. Gurnaud, Y. Souchon, and P. Lim, 2003. A Population Dynamics Model and Habitat Simulation as a Tool to Predict Brown Trout Demography in Natural and Bypassed Stream Reaches. River Research and Applications 19:551-568.

Cattanéo, F., N. Lamouroux, P. Breil, and H. Capra, 2002. The Influence of Hydrological and Biotic Processes on Brown Trout (Salmo Trutta) Population Dynamics. Canadian Journal of Fisheries and Aquatic Sciences 59:12-22.

Cottingham, P., M.C. Thoms, and G.P. Quinn, 2002. Scientific Panels and Their Use in Environmental Flow Assessment in Australia. Australian Journal of Water Resources 5:103-111.

Crowder, D.W. and P. Diplas, 2006. Applying Spatial Hydraulic Principles to Quantify Stream Habitat. River Research and Applications 22:79-90.

Davies, B.R., A. Hall, and P.B.N. Jackson, 1995. Some Ecological Aspects of the Cahora Bassa Dam. Biological Conservation 8:189-201.

Dyer, F.J. and M.C. Thoms, 2006. Managing River Flows for Hydraulic Diversity: An Example of an Upland Regulated Gravel-Bed River. River Research and Applications 22:257-268.

Extence, C.A., D.M. Balbi, and R.P. Chadd, 1999. River Flow Indexing Using British Benthic Macroinvertebrates: A Framework for Setting Hydroecological Objectives. Regulated Rivers 15:543-574.

Fausch, K.D., Y. Taniguchi, G.D. Grossman, and C.R. Townsend, 2001. Flood Disturbance Regimes Influence Rainbow Invasion Success Among Five Holarctic Regions. Ecological Applications 11:1438-1455

Fraser, J.C., 1972. Regulated Discharge and the Stream Environment. In: River Ecology and Man, R.T. Oglesby, C.A. Carlson, and J.A. McCann (Editors). Academic Press, New York, pp. 63286.

Galat, D.L. and R. Lipkin, 2000. Restoring the Ecological Integrity of Great Rivers: Historical Hydrographs Aid in Defi ning Reference Conditions for the Missouri River. In: Assessing the Ecological Integrity of Running Waters, Development in Hydrobiology 149, M. Jungwirth, S. Muhar, and S. Schmutz (Editors). Kluwer Academic, Dordrecht, pp. 29-48.

Gill, M.A., 1971. Damming the McKenzie: A Theoretical Assessment of the Long-Term Influence of Impoundment on the Ecology of the MacKenzie River Delta. In: Proceedings Peace Athabaska Delta Symposium, Water Resources Centre, University of Alberta, Edmonton, Alberta, pp. 204-222.

Gore, J.A., 1978. Technique for Predicting Instream Flow Requirements of Benthic Macroinvertebrates. Freshwater Biology 8:141-151.

Gore, J.A. and J.M. Nestler, 1988. Instream Flow Studies in Perspective. Regulated Rivers 2:93-101.

Gouraud, V., J.L. Baglinière, P. Baran, C. Sabaton, P. Lim, and D. Ombredane, 2001. Factors Regulating Brown Trout Populations 
in Two French Rivers: Application of a Dynamic Population Model. Regulated Rivers 17:557-569.

Grand, T.C., S. Railsback, J.W. Hayse, and K.E. Lagory, 2006. A Physical Habitat Model for Predicting the Effects of Flow Fluctuations in Nursery Habitats of the Endangered Colorado Pikeminnow (Ptychocheilus Lucius). River Research and Applications 22:1125-1142.

Gurnell, A.M. and G.E. Petts, 2002. Island-Dominated Landscapes of Large Floodplain Rivers, a European Perspective. Freshwater Biology 47:581-600.

Gurnell, A.M., K. Tockner, P. Edwards, and G.E. Petts, 2005. Effects of Deposited Wood on Biocomplexity of River Corridors. Frontiers in Ecology and Environment 3:377-382.

Halleraker, J.H., H. Sundt, K.T. Alfredsen, and G. Dangelmaier, 2007. Application of Multiscale Environmental Flow Methodologies as Tools for Optimized Management of a Norwegian Regulated National Salmoin Watercourse. River Research and Applications 23:493-510.

Halls, A.S. and R.L. Welcomme, 2004. Dynamics of River Fish Populations in Response to Hydrological Conditions: A Simulation Study. River Research and Applications 20:985-1000.

Hannah, D.M., B.P.G. Smith, A.M. Gurnel, and G.R. McGregor, 2000. An Approach to Hydrograph Classification. Hydrological Processes 14:317-338.

Hardy, A., J.-M. Olivier, S. Merigoux, and E. Malet, 2007. A Mesohabitat Method Used to Assess Minimum Flow Changes and Impacts on the Invertebrate and Fish Fauna in the Rhone River, France. River Research and Application 23:525544 .

Hardy, T.B., 1998. The Future of Habitat Modelling and Instream Flow Assessment Techniques. Regulated Rivers 14:405-420.

Harris, N., A.M. Gurnell, D.M. Hannah, and G.E. Petts, 2000. Classification of River Regimes: A Context for Hydroecology. Hydrological Processes 14:2831-2848.

Housego, R.E., G.R. McGregor, J.C. Kings, and S.A. Harangozo, 1998. Climate Anomaly Wave-Train Patterns Linking Southern Low and High Latitudes during South Pacific Warm and Cold Events. International Journal of Climatology 18:1181-1193.

HP, 1997. Freshwater Ecosystems and Climate Change in North America. Hydrological Processes, Special Issue, 11:817-1067.

Huckstorf, V., W.C. Lewin, and C. Wolter, 2008. Environmental Flow Methodologies to Protect Fisheries Resources in HumanModified Large Lowland Rivers. River Research and Applications 24:519-527.

Huusko, A., L. Greenberg, M. Stickler, T. Linnansaari, M. Nykänen, T. Vehanen, S. Koljonen, P. Louhi, and K. Alfredsen, 2007. Life in the Ice Lane: The Winter Ecology of Stream Salmonids. River Research and Applications 23:469-492.

Hynes, H.B.N., 1970. The Ecology of Running Waters. Liverpool University Press, Liverpool, United Kingdom.

Jacobson, R.A., 2008. Applications of Mesohabsim Using Fish Community Targets. River Research and Applications 24:434438.

Kelly, M.H. and J.A. Gore, 2007. Florida River Flow Patterns and the Atlantic Multidecadal Oscillation. River Research and Applications 24:598-616.

King, J.M., C. Brown, and H. Sabet, 2003. A Scenario-Based Holistic Approach to Environmental Flow Assessments for Rivers. River Research and Applications 19:619-639.

King, J. and D. Louw, 1998. Instream Flows Assessments for Regulated Rivers in South Africa Using the Building Block Methodology. Aquatic Ecosystem Health and Management 1:109124.

Kondolf, G.M., E.W. Larsen, and J.G. Williams, 2000. Measuring and Modelling the Hydraulic Environment for Assessing Instream Flows. North American Journal of Fisheries Management 20:1016-1028.
Lamouroux, N., H. Capra, M. Pouilly, and Y. Souchon, 1999. Fish Habitat Preferences in Large Streams of Southern France. Freshwater Biology 42:673-687.

Langbein, W.B. and J.V.B. Wells, 1955. The Water in Rivers and Creeks. Water U.S. Department of Agriculture Yearbook, Washington, D.C., pp. 52-62.

Leopold, L.B. and T. Maddock, 1953. The Hydraulic Geometry of Stream Channels and Some Physiographic Implications. US Geological Survey Professional Paper 252, Washington, D.C.

Liu, C. and B. Men, 2007. An Ecological Hydraulic Radius Approach to Estimate the Instream Ecological Water Requirement. Progress in Natural Science 17:320-327.

Lobon-Cervia, J., 2003. Spatio-Temporal Dynamics of Brown Trout Production in a Cantabrian Stream: Effects of Density and Habitat Quality. Transactions of the American Fisheries Society 132:621-637.

Lytle, D.A. and N.L. Poff, 2004. Adaptation to Natural Flow Regimes. Trends in Ecology and Evolution 19:94-100.

Mathews, R. and B.D. Richter, 2007. Application of the Indicators of Hydrologic Alteration Software in Environmental Flow Setting. Journal of the American Water Resources Association 43:1400-1413.

McKenney, R., R.B. Jacobsen, and R.C. Wertheimer, 1995. Woody Vegetation and Channel Morphogenisis in Low-Gradient, Gravel-Bed Streams in the Ozark Plateaux Missouri and Arkansas. Geomorphology 13:175-198.

Mitro, M.G., A.V. Zale, and B.A. Rich, 2003. The Relation Between Age-0 Rainbow Trout (Oncorhynchus Mykiss) Abundance and Winter Discharge in a Regulated River. Canadian Journal of Fisheries and Aquatic Sciences 60:135-139.

Molles, M.C. and C.N. Dahm, 1990. A Perspective on El Nino and La Nina: Global Implications for Stream Ecology. Journal of the North American Benthological Society 9:68-76.

Molles, M.C., C.N. Dahm, and M.T. Crocker, 1992. Climatic Variability and Rivers in Semi-Arid Regions. In: Aquatic Ecosystems in Semi-Arid Regions: Implications for Resource Management, R.D. Roberts and M.L. Bothwell (Editors). N.H.R.I. Symposium Series 7, Environment Canada, Saskatoon, Canada, pp. 197-202.

Monk, W.A., P.J. Wood, and D.M. Hannah, 2007a. Examining the Influence of Flow Regime Variability on Instream Ecology. In: Hydroecology and Ecohydrology: Past, Present and Future, P.J. Wood, D.M. Hannah, and J.P. Sadler (Editors). Wiley, Chichester, United Kingdom, pp. 165-184.

Monk, W.A., P.J. Wood, D.M. Hannah, and D.A. Wilson, 2007b. Selection of River Flow Indices for the Assessment of Hydroecological Change. River Research and Applications 23:113-122.

Monk, W.A., P.J. Wood, D.M. Hannah, and D.A. Wilson, 2008. Macroinvertebrate Community Response to Inter-Annual and Regional Flow Regime Dynamics. River Research and Applications 24:988-1001.

Monk, W.A., P.J. Wood, D.M. Hannah, A. Wilson, C.A. Extence, and R.P. Chadd, 2006. Flow Variability and Macroinvertebrate Community Response Within Riverine Systems. River Research and Applications 22:595-615.

Morales, Y., L.J. Weber, A.E. Mynett, and T.J. Newton, 2006a. Mussel Dynamics Model: A Hydroinformatics Tool for Analyzing the Effect of Different Stressors on the Dynamics of Freshwater Mussel Communities. Ecological Modelling 197:448-460.

Morales, Y., L.J. Weber, A.E. Mynett, and T.J. Newton, 2006b. Effect of Substrate and Hydrodynamic Conditions on the Formation of Mussel Beds in a Large River. Journal of the North American Benthological Society 25:664-676.

Mouton, A., H. Meixner, P.L.M. Goethals, N. de Pauw, and H. Mader, 2007. Concept and Application of the Usable Volume for Modelling the Physical Habitat of Riverine Organisms. River Research and Applications 23(5):545-558. 
Naiman, R.J., S.E. Bunn, C. Nilsson, G.E. Petts, G. Pinay, and L.C. Thompson, 2002. Legitimizing Fluvial Ecosystems as Users of Water: An Overview. Environmental Management 30:455467.

Nestler, J.M., R.A. Goodwin, and D.P. Loucks, 2005. Coupling of Engineering and Biological Models for Ecosystem Analysis. Journal of Water Resources Planning and Management 131:101-109.

Newson, M.D., D.M. Harper, C.L. Padmore, J.L. Kemp, and B. Vogel, 1998. A Cost Effective Approach for Linking Habitats, Flow Types and Species Requirements. Aquatic Conservation 8:431446.

Newson, M.D. and C.L. Newson, 2000. Geomorphology, Ecology and River Channel Habitat: Mesoscale to Basin-Scale Challenges. Progress in Physical Geography 24:195-217.

NRC, 2008. Hydrology, Ecology and Fishes of the Klamath River Basin. National Research Council of the National Academy of Sciences, The National Academy Press, Washington, D.C.

Olden, J. and N.L. Poff, 2003. Redundancy and the Choice of Hydrologic Indices for Characterizing Streamflow Regimes. River Research and Applications 19:101-121.

Orsborn, J.F. and C.H. Allman (Editors), 1976. Instream Flow Needs, Proceedings of the Boise Symposium, Idaho, May 1976. American Fisheries Society, Bethesda, Maryland.

Orth, D.J., 1987. Ecological Considerations in the Development and Application of Instream Flow-Habitat Models. Regulated Rivers 1:171-181.

Parasiewicz, P., 2003. Upscaling: Integrating Habitat Model Into River Management. Canadian Water Resources Journal, Special Issue on Habitat Modelling and Conservation of Flows, 28:283299.

Parasiewicz, P., 2007. The MesoHABSIM Model Revisited. River Research and Applications 23:893-903.

Parasiewicz, P., 2008. Application of MesoHABSIM and Target Fish Community Approaches to Restoration of the Quinebaug River, Connecticut and Massachusetts, USA. River Research and Applications 24:459-471.

Parde, M., 1955. Fleuves et Rivieres. Colin, Paris.

Penaz, M., F. Kubicek, P. Marvan, and M. Zelinka, 1968. Influence of the Vir River Valley Reservoir on the Hydrobiologiocal and Ichthyological Conditions in the River Svratka. Acta Scientiarum Naturalium Academiae Scientiarum Bohemoslovacae-Brno 2:1-60.

Petts, G.E., 1984. Impounded Rivers. Wiley, Chichester, United Kingdom.

Petts, G.E., 1996. Water Allocation to Protect River Ecosystems. Regulated Rivers 12:353-367.

Petts, G.E., 2007. Hydroecology and Water Resources Management. In: Hydroecology and Ecohydrology: Past, Present and Future, P.J. Wood, D. Hannah, and J.P. Sadler (Editors). Wiley, Chichester, United Kingdom, pp. 205-252.

Petts, G.E., M.A. Bickerton, C. Crawford, D.N. Lerner, and D. Evans, 1999. Flow Management to Sustain Groundwater-Dominated Stream Ecosystems. Hydrological Processes 13:497-513.

Petts, G.E. and I. Maddock, 1994. Flow Allocation for In-River Needs. In: The Rivers Handbook, 2, P. Calow and G.E. Petts (Editors). Blackwell Scientific Publications, Oxford, United Kingdom, pp. 289-307.

Petts, G.E., J. Nestler, and R. Kennedy, 2006. Advancing Science for Water Resources Management. Hydrobiologia 565:277-288.

Petts, G.E., R. Sparks, and I. Campbell, 2000. River Restoration in Developed Economies. In: Global Perspectives on River Conservation, P.J. Boon, B.R. Davies, and G.E. Petts (Editors). Wiley, Chichester, United Kingdom, pp. 493-508.

Poff, N.L., J.D. Allan, M.B. Bain, J.R. Karr, K.L. Prestegaard, B.D. Richter, R.E. Sparks, and J.C. Stromberg, 1997. The Natural Flow Regime. BioScience 47:769-784.
Poff, N.L., B.D. Richter, A.H. Arthington, S.E. Bunn, R.J. Naiman, E. Kendy, M. Acreman, C. Apse, B.P. Bledsoe, M.C. Freeman, J. Henriksen, R.B. Jacobsen, J.G. Kennen, D.M. Merritt, J.H. O'Keeffe, J.D. Olden, K. Rogers, R.E. Tharme, and A. Warner, 2009. The Ecological Limits of Hydrologic Alteration (ELOHA): A New Framework for Developing Regional Environmental Flow Standards. Freshwater Biology (In press).

Poff, N.L. and J.K.H. Zimmerman, 2009. Ecological Responses to Altered Flow Regimes: A Literature Review to Inform Environmental Flows Science and Management. Freshwater Biology (In press).

Postel, S.L. and B. Richter, 2003. Rivers for Life. Island Press, Washington, D.C.

Richter, B.D., J.V. Baumgartner, D.P. Braun, and J. Powell, 1998. A Spatial Assessment of Hydrological Alteration Within a River Network. Regulated Rivers 14:329-340.

Richter, B.D., J.V. Baumgartner, J. Powell, and P.D. Braun, 1996. A Method for Assessing Hydrologic Alteration Within Ecosystems. Conservation Biology 10:1163-1174.

Richter, B.D., J.V. Baumgartner, R. Wingington, and R.D. Braun, 1997. How Much Water Does a River Need? Freshwater Biology 37:231-249.

Richter, B.D., A.T. Warner, J.L. Meyer, and K. Lutz, 2006. A Collaborative and Adaptive Process for Developing Environmental Flow Recommendations. River Research and Applications 22:297-318.

Rogers, P., 2008. Facing the Freshwater Crisis. Scientific American, August, 28-35.

RRA, 2003. Environmental Flows for River Systems. River Research and Applications, Special Issue, 19(5-6):375-681.

RRA, 2007. European Aquatic Modelling Network. River Research and Applications Special Issue 23(5):467-558.

Sabaton, C., L. Siegler, V. Gouraud, J.L. Bagliniere, and S. Manne, 1997. Presentation and First Applications of a Dynamic Population Model for Brown Trout (Salmo Trutta L.): Aid to River Management. Fisheries Management and Ecology 4:425438.

Schweizer, S., M.E. Borsuk, I. Jowett, and P. Reichert, 2007. Predicting Joint Frequency Distributions of Depth and Velocity for Instream Habitat Assessment. River Research and Applications 23:287-302.

Sheail, J., 1984. Constraints on Water-Resource Development in England and Wales, Concept and Management of Compensation Flows. Journal of Environmental Management 19:351-361.

Sheail, J., 1988. River Regulation in the United Kingdom: An Historical Perspective. Regulated Rivers 2:221-232.

Shiau, J.-T. and F.-C. Wu, 2004. Assessment of Hydrologic Alterations by Chi-Chi Diversion Weir in Chou-Shui Creek, Taiwan: Opportunities for Restoring Natural Flow Conditions. River Research and Applications 20:401-412.

Shiau, J.-T. and F.-C. Wu, 2006. Compromise Programming Methodology for Determining Instream Flow Under Multiobjective Water Allocation Criteria. Journal of the American Water Resources Association 42:1179-1191.

Shiau, J.-T. and F.-C. Wu, 2007. A Dynamic Corridor Searching Algorithm to Seek Time-Varying Instream Flow Releases for Optimal Weir Operations Comparing Three Indices of Overall Hydrologic Alteration. River Research and Applications 23:35-53.

Shiau, J.-T. and F.-C. Wu, 2008. A Histogram Approach for Assessment of Flow Regime Alteration: Applications to Environmental Flow Optimization. River Research and Application 24:914-928.

Stalnaker, C.B., 1979. The Use of Habitat Structure Preferenda for Establishing Flow Regimes Necessary for Maintenance of Fish Habitat. In: The Ecology of Regulated Streams, J.V. Ward and J.A. Stanford (Editors). Plenum Press, New York, pp. 321-338.

Stalnaker, C.B., 1994. Evolution of Instream Flow Habitat Modelling. In: The Rivers Handbook, 2, P. Calow and G.E. Petts 
(Editors). Blackwell Scientific Publications, Oxford, United Kingdom, pp. 276-288.

Stalnaker, C.B., K.D. Bovee, and T.J. Waddle, 1996. Importance of the Temporal Aspects of Habitat Dynamics to Fish Population Studies. Regulated Rivers 12:145-153.

Stanford, J.A., J.V. Ward, W.J. Liss, C.A. Frissell, et al., 1996. A General Protocol for Restoration of Regulated Rivers. Regulated Rivers 12:391-413.

Statzner, B., J.A. Gore, and V.H. Resh, 1988. Hydraulic Stream Ecology: Observed Patterns and Potential Applications. Journal North American Benthological Society 7:307-360.

Steel, E.A. and I.A. Lange, 2007. Using Wavelet Analysis to Detect Changes in Water Temperature Regimes at Multiple Scales: Effects of Multi-Purpose Dams in the Willamette River Basin. River Research and Applications 23:351-360.

Stewart, G., R. Anderson, and E. Wohl, 2005. Two-Dimensional Modelling of Habitat Suitability as a Function of Discharge on Two Colorado Rivers. River Research and Applications 21:10611074.

Strayer, D.L., J.A. Downing, W.R. Haag, T.L. King, J.B. Layzer, T.J. Newton, and S.J. Nichols, 2004. Changing Perspectives on Pearly Mussels, North America's Most Imperiled Animals. BioScience 54:429-439.

Tennant, D.L., 1976. Instream Flow Requirements for Fish, Wildlife, Recreation and Related Environmental Resources. Fisheries 1:6-10.

Tharme, E., 2003. A Global Perspective on Environmental Flow Assessment: Emerging Trends in the Development and Application of Environmental Flow Methodologies for Rivers. River Research and Applications 19:397-442.

Thomas W.L. Jr. (Editor), 1956. Man's Role in Changing the Face of the Earth. University of Chicago Press, Chicago, Illinois.

Vadas, R.L. and D.J. Orth, 2001. Formulation of Habitat Suitability Models for Stream Fish Guilds: Do the Standard Methods Work. Transactions of the American Fisheries Society 130:217-235.

Ward, J.V., 1976. Comparative Limnology of Differentially Regulated Sections of a Colorado Mountain River. Archiv für Hydrobiologie 78:319-342.

Ward, J.V., J.A., Stanford (Editors), 1979. The Ecology of Regulated Streams. Plenum Press, New York.

Welcomme, R.L., 1979. Fisheries Ecology of Floodplain Rivers. Longman, London.

White, M.A., J.C. Schmidt, and D.J. Topping, 2005. Application of Wavelet Analysis for Monitoring the Hydrological Effects of Dam Operation: Glen Canyon Dam and the Colorado River at Lees Ferry, Arizona. River Research and Applications 21:551566.

Young, W.J., B.C. Chessman, W.D. Erskine, T.A. Raadik, D.J. Wimbush, J. Tilleard, A.J. Jakeman, I. Varley, and J. Verhoeven, 2004. Improving Expert Panel Assessments Through the Use of a Composite River Consition Index - The Case of the Rivers Affected by the Snowy Mountains Hydroelectric Scheme, Australia. River Research and Applications 20:733-750. 